\title{
Cox2 community barcoding at Prince Edward Island reveals long-distance dispersal of a downy mildew species and potentially marine members of the Saprolegniaceae
}

\author{
Julia A. F. Langer ${ }^{1}$ - Rahul Sharma ${ }^{2,3} \cdot$ Bora Nam $^{2,3}$ - Louis Hanic ${ }^{4}$ Maarten Boersma ${ }^{1,5}$. \\ Klaus Schwenk ${ }^{2,6}$. Marco Thines ${ }^{2,3}$ (D)
}

Received: 24 December 2020 / Revised: 9 February 2021 / Accepted: 15 February 2021

(C) The Author(s) 2021

\begin{abstract}
Marine oomycetes are highly diverse, globally distributed, and play key roles in marine food webs as decomposers, food source, and parasites. Despite their potential importance in global ocean ecosystems, marine oomycetes are comparatively little studied. Here, we tested if the primer pair cox $2 \mathrm{~F}$ Hud and cox2-RC4, which is already well-established for phylogenetic investigations of terrestrial oomycetes, can also be used for high-throughput community barcoding. Community barcoding of a plankton sample from Brudenell River (Prince Edward Island, Canada), revealed six distinct oomycete OTU clusters. Two of these clusters corresponded to members of the Peronosporaceae - one could be assigned to Peronospora verna, an obligate biotrophic pathogen of the terrestrial plant Veronica serpyllifolia and related species, the other was closely related to Globisporangium rostratum. While the detection of the former in the sample is likely due to long-distance dispersal from the island, the latter might be a bona fide marine species, as several cultivable species of the Peronosporaceae are known to withstand high salt concentrations. Two OTU lineages could be assigned to the Saprolegniaceae. While these might represent marine species of the otherwise terrestrial genus, it is also conceivable that they were introduced on detritus from the island. Two additional OTU clusters were grouped with the early-diverging oomycete lineages but could not be assigned to a specific family. This reflects the current underrepresentation of $\operatorname{cox} 2$ sequence data which will hopefully improve with the increasing interest in marine oomycetes.
\end{abstract}

Keywords Brudenell River $\cdot$ Canada $\cdot$ Community barcoding $\cdot \operatorname{cox} 2 \cdot$ Marine ecosystem $\cdot$ Oomycetes $\cdot$ Peronosporaceae

\section{Introduction}

Section Editor: Marc Stadler

Marco Thines

m.thines@thines-lab.eu

1 Biologische Anstalt Helgoland, Alfred-Wegener-Institut Helmholtz-Zentrum für Polar-und Meeresforschung, Helgoland Germany

2 Biodiversity and Climate Research Centre (BiK-F), Senckenberg Gesellschaft für Naturkunde, Frankfurt am Main Germany

3 Faculty of Biological Sciences, Institute of Ecology, Evolution and Diversity, Frankfurt am Main Germany

4 Department of Biology, University of Prince Edward Island, Charlottetown Canada

5 University of Bremen, Bremen Germany

6 Institute of Environmental Science, University of Koblenz-Landau, Landau in der Pfalz Germany
Oomycetes are a diverse group of fungus-like eukaryotic microorganisms occurring in terrestrial, limnic and marine habitats worldwide. They are classified within the kingdom Straminipila together with diatoms, golden-brown and brown algae (Baldauf 2003). Oomycete species are nonphotosynthetic and exhibit either a saprophytic or a pathogenic lifestyle (Grenville-Briggs and van West 2005; Thines 2014). Saprotrophic oomycetes absorb nutrients from the dead organic substrates they colonise, thereby playing an important role in the decomposition and recycling of decaying matter (Marano et al. 2016). In addition, oomycete zoospores substantially contribute to the pool of heterotrophic flagellates in the plankton of marine habitats (Sime-Ngando et al. 2011). Thereby, zoospores serve as source of essential compounds, such as polyunsaturated fatty acids (PUFAs) and sterols for zooplankton organisms (Marano et al. 2016). 
Representatives of the oomycetes are common in marine environments (Grenville-Briggs et al. 2011) and well-known to infect several planktonic (Drebes 1966; Gotelli 1971; Hanic et al. 2009; Sparrow 1969) and benthic diatoms (Scholz et al. 2014; Scholz et al. 2016) as well as macroalgal and seagrass species (Govers et al. 2016; Sekimoto et al. 2008a; Sekimoto et al. 2008b), and nematodes (Beakes et al. 2012). Diatom pathogens are potentially of great ecological importance as they might play a role in the breakdown of plankton blooms (Thines et al. 2015). Although parasitism is a frequent strategy in most natural habitats, infectious disease agents were only recently considered in food web analyses (Lafferty et al. 2008). Thompson et al. (2005) showed that parasites have the potential to uniquely alter marine food web topology, especially in terms of chain length and the proportions of top, intermediate and basal level species. Furthermore, parasites and pathogens might also influence food web stability and energy flow and should therefore receive more attention in future investigations of marine food webs.

As the most basal lineages of the Oomycota are predominantly marine parasites (Beakes et al. 2012), oomycetes have most likely evolved in the marine realm (Thines 2014). However, of the roughly 2000 reported oomycetes species so far, only about 60 have been described from marine environments (Sparrow 1960; Nigrelli and Thines 2013; Bennett and Thines 2020; Buaya and Thines 2020a). The identification of marine oomycetes using morphological methods is labour-intensive and time-consuming. In addition, species determination is challenging due to the limited amount of available morphological characters (Bennett et al. 2017; Bennett and Thines 2020). Several studies using molecular biological methods have already revealed that morphological investigations have largely underestimated the diversity of terrestrial, limnic and marine oomycetes (Bala et al. 2010; Hulvey et al. 2010; Man in 't Veld et al. 2011; Singer et al. 2016; Thines and Choi 2016). Furthermore, their impact on marine ecosystems and/or prevalence in marine biotas remain virtually unknown, despite some recent advances (Garvetto et al. 2018; Hassett et al. 2019).

Community barcoding (DNA barcoding in combination with high-throughput sequencing) can provide a fast and accurate method to identify marine oomycete species with high taxonomic resolution directly from a mixed plankton water sample. In the TARA project, this technique was already successfully used to explore patterns of the global photic-zone eukaryotic plankton biodiversity, including oomycota (de Vargas et al. 2015). Also utilising community barcoding, Singer et al. (2016) detected highly diverse oomycete communities in peat bog micro-habitats. However, both studies were based on the analysis of the V9 region of the nuclear gene that encodes 18S rRNA, which on the one hand allows the detection of a broad range of eukaryotic taxa but on the other hand does not show a high resolution on the species and even genus level. The most common gene region currently used for the identification of oomycetes to the genus or species level is the internal transcribed spacer (ITS) region of rDNA (Robideau et al. 2011). However, due to the lack of functional constrains on this untranslated gene region, alignments of ITS sequences can be hampered by large amounts of insertions and deletions, which complicate species classification. Additionally, differences in alleles or among the multiple copies of the ITS can even lead to the appearance of indels within a single oomycete strain, as observed by Kageyama et al. (2007). Furthermore, the resolution of ITS is insufficient to discriminate between species in some groups (Choi et al. 2015b).

Based on the study of Choi et al. (2015a), the cox2 locus seems to be an appropriate gene region to serve as a universal barcode for the investigation of oomycetes, according to the PCR efficiency and in terms of the intraspecific and interspecific divergence. Furthermore, the cox 2 locus was already widely used in phylogenetic studies of various oomycete species, wherefore the amount of available reference sequences, especially for terrestrial species, is accordingly high (Choi et al. (2015) and references therein). In comparison to cox 1 , cox 2 has some advantages, as it is more readily amplifiable throughout oomycete diversity, has a slightly better performance in delimitating species, and offers the possibility to work with a partial barcode for short-read sequencing if desired, due to an internal conserved region (Choi et al. 2015b). Thus, we explore cox2-barcoding, which provides a high taxonomic resolution on the species level, to assess the presence and diversity of oomycetes off the shore of Prince Edward Island (Canada).

\section{Methods}

The sample analysed in this study was taken in November 2012 in the mouth of Brudenell River, Prince Edward Island (PEI), which is a monitoring site for the occurrence of toxic diatom blooms and can stand exemplary for samples from a coast-shelf transition zone. The sampling took place within the framework of the PEI Mussel Monitoring Program (Smith and Ramsay 2012) which was carried out from September 4 to December 13. For the sampling, an Apstein net $(20-\mu \mathrm{m}$ mesh size, 1-m long, Hydro-Bios) was towed through the water for $100 \mathrm{~m}$ around $1 \mathrm{~km}$ from the shore. The concentrated plankton sample was rinsed into a $100-\mathrm{mL}$ bottle and filled up with $90 \%$ pure ethanol. The sample was shipped to Germany and stored at $-80{ }^{\circ} \mathrm{C}$ until DNA extraction.

\section{DNA isolation and PCR}

DNA isolation was performed using the innuPREP Plant DNA Kit from Analytic Jena AG, Jena, Germany, following 
the instructions of the manual for gDNA isolation from plant material. From the $100-\mathrm{mL}$ bottle, $\sim 150 \mathrm{mg}$ of sample was transferred to a $2-\mathrm{mL}$ tube and homogenised for $5 \mathrm{~min}$ at $25 \mathrm{~Hz}$ with the Mixer Mill MM 200 (Retsch, Haan, Germany after adding metal beads of $3 \mathrm{~mm}$ and $1 \mathrm{~mm}$ in diametre). As modifications form the instructions of the manufacturer, lysis was carried out for $60 \mathrm{~min}$, and for the final DNA elution, we used $50 \mu \mathrm{L}$ of elution buffer. Until further use, the isolated DNA and the remaining part of the plankton sample were stored at $-20^{\circ} \mathrm{C}$ and $-80^{\circ} \mathrm{C}$, respectively.

For the community barcoding, the gene region cox 2 was amplified using the primer pair cox $2 \mathrm{~F} \_$Hud $\left(5^{\prime}\right.$-GGCA AATGGGTTTTCAAGATCC-3') and cox2-RC4 (5'ATTWAYNCCACAAATTTCRCTACATTG-3') (Choi et al. 2015; Hudspeth et al. 2003). Amplification was carried out in a total volume of $25 \mu \mathrm{L}$ using $\sim 10 \mathrm{ng}$ DNA. The reaction mix contained $1 \times$ Phusion HF buffer, $0.2 \mathrm{mM}$ dNTPs, $0.5 \mu \mathrm{M}$ of each primer and 0.5 units Phusion polymerase. PCR conditions were 2 min at $95{ }^{\circ} \mathrm{C}$, followed by 35 cycles of $20 \mathrm{~s}$ at $95^{\circ} \mathrm{C}, 30 \mathrm{~s}$ at $50{ }^{\circ} \mathrm{C}$, and $1 \mathrm{~min}$ at $72{ }^{\circ} \mathrm{C}$, and a final elongation for $6 \mathrm{~min}$ at $72{ }^{\circ} \mathrm{C}$. PCR products were sent to Eurofins Genomics (Ebersberg, Germany) for library preparation and sequencing on an Illumina MiSeq platform using the paired-end $(2 \times 300 \mathrm{bp})$ option. Sequence reads were deposited in the European Nucleotide Archive (PRJEB25385).

\section{Illumina data processing}

The Illumina adapter and primer sequences of the raw sequence pairs were trimmed using Trimmomatic (Bolger et al. 2014). Quality filtration was performed using a window size of $5 \mathrm{bp}$ with an average phred quality score of 25 and a read length cutoff of $220 \mathrm{bp}$. Furthermore, sequences including ambiguous bases (Ns) were deleted, and sequences were again filtered by keeping a minimum quality phred score of 3 per base using FastQFS (Sharma and Thines 2015). Afterwards, related forward and reverse reads were concatenated using custom perl scripts. Then the primer sequences were trimmed, and all reads were oriented in $5^{\prime}-3^{\prime}$ direction. The prediction of operational taxonomical units (OTUs) was carried out with the USEARCH v7 software (Edgar 2010). For this, both a de-novo and a reference-based chimera filters were applied. The minimum cluster size was three reads using an identity cutoff of $99 \%$.

\section{Phylogenetic analyses}

To separate the oomycete OTUs from other eukaryotic OTUs, we first aligned the OTU sequences with the NCBI nucleotide database (nt) using the BLASTn (Altschul et al. 1990) algorithm and further analysed the result with MEGAN (Huson et al. 2007). All OTU sequences which were assigned to oomycetes were extracted and used for the subsequent phylogenetic analyses. In addition, all OTUs were subjected to BLASTn searchers against nt and top hits as well as related species were added to the dataset. Subsequently, we generated an alignment using MUSCLE (Edgar 2004) with default settings as implemented in MEGA 7.0.26 (Tamura et al. 2011). Sequences related to amplification artefacts (non-homologous amplification) were manually detected based on their lack of homology to the target regions and deleted from the set. Afterwards sequences were trimmed to the same length. The refined alignment (Supplementary information 1) was used for the subsequent phylogenetic inference in MEGA 7.0.26. Minimum evolution (ME) inference was calculated with 1000 bootstrap replicates using the same software using and applying the Tamura-Nei substitution model and default settings. Maximum-likelihood (ML) inference was calculated, with 1000 bootstrap replicates using the Tamura-Nei substitution model with 4 Gamma categories.

\section{Results}

\section{Illumina data processing}

The Illumina MiSeq sequencing resulted in about 9 million paired-end sequence reads. The raw reads were processed for Illumina adapter and primer sequences, and filtered in terms of their sequencing quality and sequenced read length. Around half $(50.9 \%)$ of the reads passed these data-processing and datafiltering steps. Afterwards, the oligomer and primer sequences were clipped off, and all sequences were oriented in $5^{\prime}$ to $3^{\prime}$ direction, which resulted in 39,041 sequences reads. In the final clustering step, we obtained 216 OTUs represented by more than three reads. In the MEGAN analysis, 33 OTUs (19\%) were assigned to different oomycete lineages. The majority of the other OTUs clustered with Straminipila and some other bikont lineages. After homology checking, 3 OTUs resulting from offtarget amplification were manually removed.

\section{Phylogenetic analyses}

The final sequence alignment included 30 oomycete OTUs and 37 reference sequences of $\sim 240$-bp length. Both of the phylogenetic analyses, ME and ML, yielded highly similar topologies, and we did not observe strongly supported inconsistencies. Hence, the bootstrap values from the ML inference were included in the figure of the ME tree (Fig. 1). In the phylogenetic analyses, the 30 oomycete OTUs clustered together in four distinct groups and two single OTUs, representing six different oomycete phylotypes. Two groups, comprising three and four OTUs each, were found to belong to the oomycetes diverging before the main split into Peronosporomycetes and Saprolegniomycetes. The groups with 12 and 9 OTUs were both allocated in the 
ME/ML

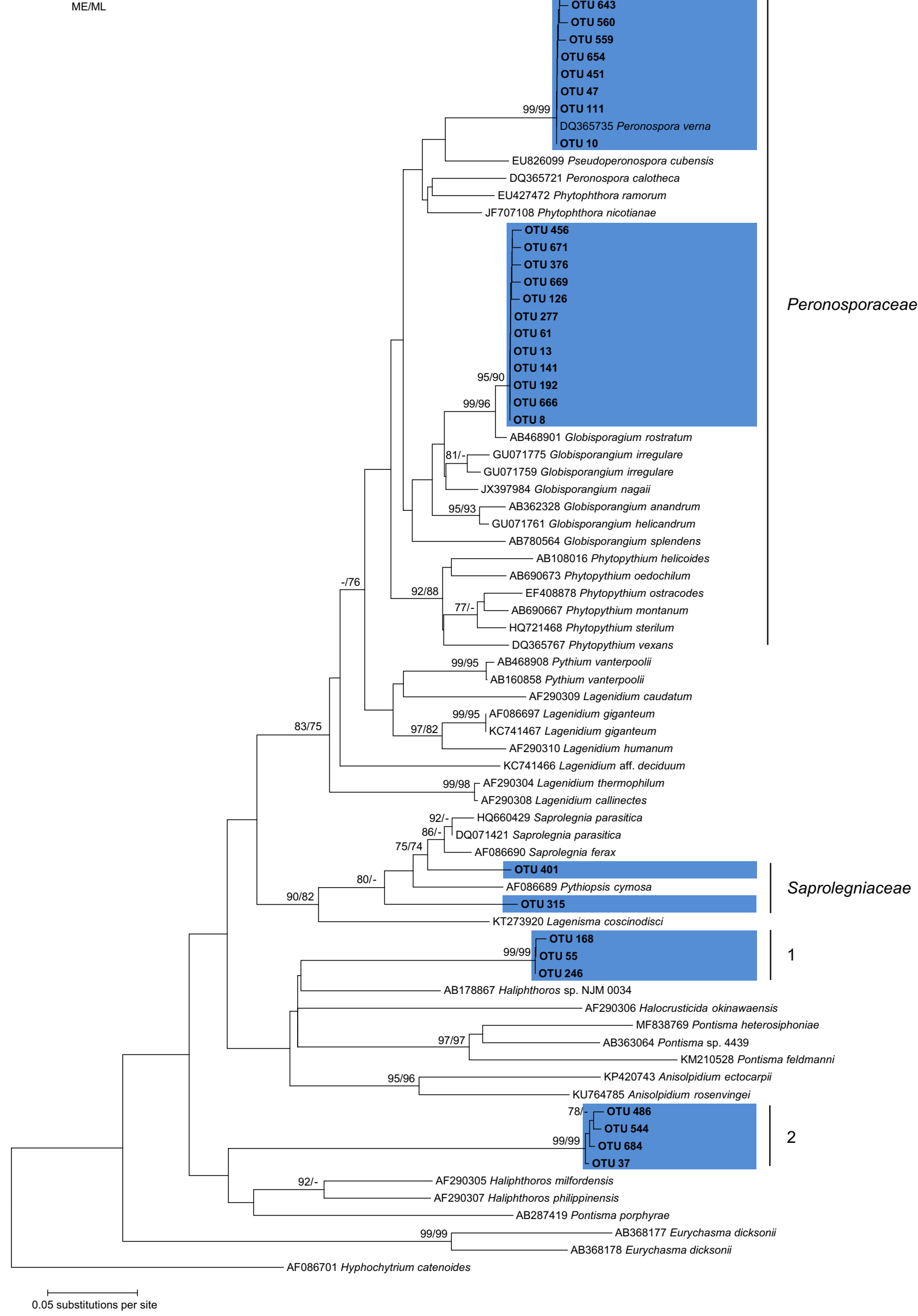


Fig. 1 Minimum Evolution phylogenetic tree inferred with MEGA 7.0.26 from the cox 2 gene region. Numbers on branches denote bootstrap values equal to or larger than $70 \%$ from 1000 replicates of the minimum-evolution and maximum-likelihood analyses, at the first and second position, respectively. Numbers next to the specific names of the reference sequences are the NCBI accession numbers. The scale bar indicates the number of substitutions per site

Peronosporaceae. While one group corresponded to Globisporangium rostratum s.1., the other represented Peronospora verna, a pathogen of Veronica serpyllifolia and related species. The two single OTUs were placed in the Saprolegniaceae, allied with the genera Pythiopsis and Saprolegnia.

\section{Discussion}

\section{Method}

The analyses of the community barcoding data resulted in a total number of 216 OTUs. MEGAN analyses showed that 33 of the OTUs derived from oomycetes, of which 3 represented off-target amplifications, probably from mitochondrial insertions in nuclear genomes. Thus, $15 \%$ of the OTUs were from the desired target group, which is much higher than with unspecific amplification of similar samples, e.g. using $18 \mathrm{~S}$ primers non-discriminating among eukaryotic linages (Langer et al. 2017). However, improvements of the specificity would be desirable, to reduce sequencing costs in large scale sampling approaches.

At first glance, community barcoding seems to have revealed rather low oomycete diversity ( 6 phylotypes) in the investigated plankton community of the Brudenell River. However, compared to the globally observed diversity of marine oomycetes in the TARA project, which encompasses 69 phylotypes from 334 size fractionated plankton samples (de Vargas et al. 2015), the six highly distinct phylotypes found in this study seems comparable. In conclusion, community barcoding using the cox 2 gene region with the primer pair cox $2 \mathrm{~F}$ _Hud and cox2-RC4 likely reflects the oomycete diversity present at the sampling site.

\section{Oomycete diversity}

The phylum Oomycota represents a large group within the Straminipila, including marine, freshwater and terrestrial species (Dick 2001a; Dick 2001b; Beakes et al. 2014; Beakes and Thines 2017). Most of the early-diverging lineages are marine organisms that are mainly parasites of seaweeds, diatoms, nematodes and crustaceans (Thines and Kamoun 2010, Buaya and Thines 2020a). Members of the most diversified classes Saprolegniomycetes and Peronosporomycetes mainly occur in freshwater and terrestrial ecosystems, even though the
Peronosporales harbour a variety of marine groups (Marano et al. 2016, Bennett and Thines 2019; Bennett and Thines 2020). Although marine oomycetes have attracted renewed interest during the last decade, little is known about their significance in ecosystem functioning (Strittmatter et al. 2008). There are reports of oomycete infections in marine primary producers (Grahame 1976; Hanic et al. 2009; Scholz et al. 2014; Wetsteyn and Peperzak 1991), but it is unclear which role these play a role in the breakdown of phytoplankton blooms.However, saprophytic and pathogenic oomycetes might have important impacts on marine ecosystem functioning including energy fluxes and overall stability (Lafferty et al. 2006; Wood et al. 2007). Besides, there is evidence that oomycetes are likely to play a significant and similarly nuanced role in the biology and abundance of their hosts (Strittmatter et al. 2008). An example for this is that Eurychasma dicksonii infection of the sessile filamentous brown alga Pylaiella littoralis might have a positive influence on its distribution, by fragmenting the thallus of its host (Wilce et al. 1982).

In line with the high genetic divergence among oomycete lineages (Buaya et al. 2020), the phylogenetic reconstruction did not resolve deep splits in Oomycota, but showed a good resolution for the terminal nodes. In our phylogenetic analyses, the two largest OTU groups were assigned to the family Peronosporaceae. Interestingly, the largest OTU cluster corresponded to Peronospora verna, a downy mildew of the terrestrial plant Veronica serpyllifolia and related species. Peronospora verna is an obligate biotrophic pathogen producing aerial conidia (Gäumann 1923). Veronica serpyllifolia has been reported from various parts of Prince Edward Island (Erskine 1960), and Peronospora species on that genus are known to occur year-round at various plant life-cycle stages (Thines and Kruse 2017). High spore loads can, therefore, occur at any time of the year, and the air-borne nature of downy mildews can also be used for an early warning system for economically important species (Klosterman et al. 2014). In conclusion, $P$. verna must have been introduced by longdistance dispersal from suitable sites on Prince Edward Island.

The second OTU that was placed in the Peronosporaceae was a member of the genus Globisporangium, closely related to G. rostratum. Globisporangium rostratum is a widespectrum opportunistic pathogen (Bruckart and Lorbeer 1982) and frequently isolated from unspecific substrates (Pottorff and Panter 1997). Several species of the Peronosporaceae, including species described in the genus Pyhtium, are known to be highly salt-tolerant (Klockkova et al. 2017), so it seems possible that the OTUs classified to $G$. rostratum s.l. correspond to a marine saprotroph or parasite. Alternatively, it is also conceivable that the species reached the marine ecosystem on plant detritus it had colonised on Prince Edward Island and was washed to the sea. Further sampling and cultivation experiments will be needed to ascertain the marine origin of this OTU. 
Two of the six phylotypes (represented by one OTU, each) were located within the Saprolegniaceae, with unclear genus affinity. This is noteworthy, as Saprolegnia is considered a terrestrial genus, with infrequent incursions in brackish environments (Höhnk 1968; Dinçtürk et al. 2019). While it seems possible that the OTUs represent marine members of the Saprolegniaceae not observed so far, it is also conceivable that, similar to the situation in G. rostratum s.l., the saprolegniaceous species were merely washed to the sea and have a terrestrial origin. The question of which oomycetes are able to make the transition between limnic, estuarine and marine habitats and at least survive for some time at higher salinity is an important knowledge gap in oomycete ecology, despite the potential importance of this knowledge for farming and aquaculture.

The two remaining OTU clusters were assigned to the early-diverging oomycetes, with unclear affinity. The earlydiverging linages are both marine and, without a known exception, parasites (Beakes et al. 2012; Buaya and Thines 2020a). During the PEI Mussel Monitoring Program, a sharp decline in the population of the marine diatom Pseudonitzschia was observed. Hanic et al. (2009) identified one oomycete parasite infecting the diatom on-site, which was recently described as a new genus and species, Miracula helgolandica (Buaya et al. 2017). It seems possible that one of the OTU clusters represents this species, but unfortunately, no $\operatorname{cox} 2$ sequence is available for this enigmatic species, yet. The other early-diverging OTU cluster might represent Diatomophthora drebesii (Buaya et al. 2017) or related species, which are also diatom parasitoids (Buaya and Thines 2020b). However, also for these species, no cox 2 sequence is available in sequence databases, yet. Thus, it remains unclear, which of the OTU clusters might be associated with either Diatomophthora or Miracula. However, both OTUs assignable to Diatomophthora and Miracula were recently found to be the most abundant in the Arctic Ocean, but also some OTUs assigned to the genus Pontisma were found frequently (Hassett et al. 2019). Even though the identity cannot be ascertained at present, with the steady growth of available sequences for the cox 2 barcoding locus (Choi et al. 2015), and the fast pace at which new oomycetes from the marine environment are being described (Hulvey et al. 2010; Bennett et al. 2017; Bennett and Thines 2017; Buaya et al. 2017, 2019; Buaya and Thines 2020a, 2020b), it seems likely that in the near future, a species-level assignment will be possible using cox2-based community sequencing.

Acknowledgements We thank the scientists from the PEI Mussel Monitoring Program for taking and providing the plankton sample. Sebastian Ploch and Lisa Nigrelli are gratefully acknowledged for laboratory support and initial handling of the sample, respectively. A preliminary version of this study has been included in the $\mathrm{PhD}$ thesis of the first author.
Author contribution MT conceived the study, LH provided the material, $\mathrm{BN}$ processed the material, JL and RS conducted bioinformatic analyses, MT did the phylogenetic reconstructions, and JL and MT wrote the manuscript with contributions from the other authors.

Funding Open Access funding enabled and organized by Projekt DEAL. This study was part of the BMBF (Bundesministerium für Bildung und Forschung)-financed BIOACID II project, consortium 1, work package 1.14 (FKZ 03F0655B). MT is supported by LOEWE in the framework of the Centre for Translational Biodiversity Genomics.

Data availability Sequence data have been deposited in GenBank.

\section{Declarations}

Ethics approval and consent to participate Not applicable.

Consent for publication Not applicable.

Competing interests The authors declare no competing interests.

Open Access This article is licensed under a Creative Commons Attribution 4.0 International License, which permits use, sharing, adaptation, distribution and reproduction in any medium or format, as long as you give appropriate credit to the original author(s) and the source, provide a link to the Creative Commons licence, and indicate if changes were made. The images or other third party material in this article are included in the article's Creative Commons licence, unless indicated otherwise in a credit line to the material. If material is not included in the article's Creative Commons licence and your intended use is not permitted by statutory regulation or exceeds the permitted use, you will need to obtain permission directly from the copyright holder. To view a copy of this licence, visit http://creativecommons.org/licenses/by/4.0/.

\section{References}

Altschul SF, Gish W, Miller W, Myers EW, Lipman DJ (1990) Basic local alignment search tool. J Mol Biol 215:403-410

Bala K, Robideau GP, Désaulniers N, de Cock A, Lévesque CA (2010) Taxonomy, DNA barcoding and phylogeny of three new species of Pythium from Canada. Persoonia 25:22-31

Baldauf SL (2003) The deep roots of eukaryotes. Science 300:1703-1706

Beakes GW, Glockling SL, Sekimoto S (2012) The evolutionary phylogeny of the oomycete "fungi". Protoplasma 249:3-19

Beakes GW, Thines M (2017) Hyphochytriomycota and Oomycota. In: Archibald J, Simpson A, Slamovits C (eds) Handbook of the Protists. Springer, Cham, pp 435-505

Beakes GW, Honda D, Thines M (2014) 3 Systematics of the Straminipila: Labyrinthulomycota, Hyphochytriomycota, and Oomycota. In: McLaughlin DJ, Spatafora JW (eds) Systematics and evolution: part A. Springer, Berlin Heidelberg, Berlin, Heidelberg, pp 39-97

Bennett RM, de Cock AWAM, Lévesque CA, Thines M (2017) Calycofera gen. nov., an estuarine sister taxon to Phytopythium, Peronosporaceae. Mycol Prog 16:947-954

Bennett RM, Thines M (2017) Confirmation that Phytophthora insolita (Peronosporaceae) is present as a marine saprotroph on mangrove leaves and first report of the species for the Philippines. Nova Hedwigia 105:185-196 
Bennett RM, Thines M (2019) Revisiting Salisapiliaceae. Fungal Systematics and Evolution 3:171-184

Bennett RM, Thines M (2020) An overview on Philippine estuarine oomycetes. Philipp J Syst Biol 14:a14007

Bolger AM, Lohse M, Usadel B (2014) Trimmomatic: a flexible trimmer for Illumina sequence data. Bioinformatics 30:2114-2120

Bruckart WL, Lorbeer JW (1982) Pythium species pathogenic to onion seedlings grown on organic soils in New York. Phytopathol 72:469475

Buaya AT, Thines M (2020a) An overview on the biology and phylogeny of the early-diverging oomycetes. Philipp J Syst Biol 14:a14004

Buaya AT, Thines M (2020b) Diatomophthoraceae-a new family of olpidiopsis-like diatom parasitoids largely unrelated to Ectrogella. FUSE 5:113-118

Buaya AT, Ploch S, Hanic L, Nam B, Nigrelli L, Kraberg AC, Thines M (2017) Phylogeny of Miracula helgolandica gen. et sp. nov. and Olpidiopsis drebesii sp. nov., two basal oomycete parasitoids of marine diatoms, with notes on the taxonomy of Ectrogella-like species. Mycol Prog 16:1041-1050

Buaya AT, Ploch S, Inaba S, Thines M (2019) Holocarpic oomycete parasitoids of red algae are not Olpidiopsis. FUSE 4:21-31

Buaya AT, Ploch S, Kraberg A, Thines M (2020a) Phylogeny and cultivation of the holocarpic oomycete Diatomophthora perforans comb. nov., an endoparasitoid of marine diatoms. Mycol Prog 19: $441-454$

Choi Y-J, Beakes G, Glockling S, Kruse J, Nam B, Nigrelli L, Ploch S, Shin H-D, Shivas RG, Telle S, Voglmayr H, Thines M (2015a) Towards a universal barcode of oomycetes-a comparison of the $\operatorname{cox} 1$ and $\operatorname{cox} 2$ loci. Mol Ecol Res 15:1275-1288

Choi Y-J, Klosterman SJ, Kummer V, Voglmayr H, Shin H-D, Thines M (2015b) Multi-locus tree and species tree approaches toward resolving a complex clade of downy mildews (Straminipila, Oomycota), including pathogens of beet and spinach. Mol Phyl Evol 86: 24-34

de Vargas C, Audic S, Henry N, Decelle J, Mahe F, Logares R, Lara E, Berney C, Bescot NL, Probert I, Carmichael M, Poulain J, Romac S, Colin S, Aury J, Bittner L, Chaffron S, Dunthorn M, Engelen S, Flegontova O, Guidi L, Horak A, Jaillon O, Lima-Mendez G, Luke J, Malviya S, Morard R, Mulot M, Scalco E, Siano R, Vincent F, Zingone A, Dimier C, Picheral M, Searson S, Kandels-Lewis S, Acinas SG, Bork P, Bowler C, Gorsky G, Grimsley N, Hingamp P, Iudicone D, Not F, Ogata H, Pesant S, Raes J, Sieracki ME, Speich S, Stemmann L, Sunagawa S, Weissenbach J, Wincker P, Karsenti E, Boss E, Follows M, Karp-Boss L, Krzic U, Reynaud EG, Sardet C, Sullivan MB, Velayoudon D, Coordinators TO (2015) Eukaryotic plankton diversity in the sunlit ocean. Science 348:126149-1-126149-10

Dick MW (2001a) Oomycota. In: McLaughlin D, McLaughlin E, Lemke CA (eds) The Mycota VII part A. Systematics and evolution. Springer, Berlin, pp 48-72

Dick MW (2001b) Straminipilous fungi: systematics of the Peronosporomycetes, including accounts of the marine straminipilous protists, the plasmodiophorids, and similar organisms. Kluwer Academic Publishers, Dordrecht

Dinçtürk E, Tanrikul TT, Birincioğlu SS (2019) First report of Saprolegnia parasitica from a marine species: Gilthead Seabream (Sparus aurata) in brackish water conditions. Journal of the Hellenic Vet Med Soc 70:1503-1510

Drebes G (1966) Ein parasitischer Phycomycet (Lagenidiales) in Coscinodiscus. Helgoländer Wiss Meeresunters 13:426-435

Edgar RC (2004) MUSCLE: multiple sequence alignment with high accuracy and high throughput. Nucleic Acids Res 32:1792-1797

Edgar RC (2010) Search and clustering orders of magnitude faster than BLAST. Bioinformatics 26:2460-2461

Erskine DS (1960) The plants of Prince Edward Island. Plant Research Institute (Research Branch), Canada Department of Agriculture, Publication 1088, Queen's Printer, Ottawa
Gäumann EA (1923) Beitrage zu einer Monographie der Gattung Peronospora Corda. Beitr Kryptogamenfl Schweiz 5:1-360

Garvetto A, Nézan E, Badis Y, Bilien G, Arce P, Bresnan E, Gachon CMM, Siano R (2018) Novel widespread marine oomycetes parasitising diatoms, including the toxic genus Pseudo-nitzschia: genetic, morphological, and ecological characterisation. Frontiers Microbiol 9:2918

Gotelli D (1971) Lagenisma coscinodisci, a parasite of the marine diatom Coscinodiscus occurring in the Puget Sound, Washington. Mycologia 63:171-174

Govers LL, Man in 't Veld WA, Meffert JP, Bouma TJ, van Rijswick PCJ, Heusinkveld JHT, Orth RJ, van Katwijk MM, van der Heide T (2016) Marine Phytophthora species can hamper conservation and restoration of vegetated coastal ecosystems. Proc R Soc B 283: 20160812

Grahame ES (1976) The occurrence of Lagenisma coscinodisci in Palmeria hardmaniana from Kingston harbor, Jamaica. Br Phycol 11:57-61

Grenville-Briggs L, Gachon CM, Strittmatter M, Sterck L, Kupper FC, van West P (2011) A molecular insight into algal-oomycete warfare: cDNA analysis of Ectocarpus siliculosus infected with the basal oomycete Eurychasma dicksonii. PloS ONE 6:e24500

Grenville-Briggs LJ, van West P (2005) The biotrophic stages of oomycete-plant interactions. Adv in Appl Microbiol 57:217-243

Hanic LA, Sekimoto S, Bates S (2009) Oomycete and chytrid infections of the marine diatom Pseudo-nitzschia pungens (Bacillariophyceae) from Prince Edward Island, Canada. Botany 87:1096-1105

Hassett BT, Thines M, Buaya A, Ploch S, Gradinger R (2019) A glimpse into the biogeography, seasonality, and ecological functions of arctic marine Oomycota. IMA Fungus 10:1-10

Höhnk W (1968) Zur Entfaltung der marinen Mykologie. Ber Deut Bot Ges 81:380-390

Hudspeth DS, Stenger DC, Hudspeth ME (2003) A cox2 phylogenetic hypothesis for the downy mildews and white rusts. Fungal Div 13: $47-57$

Hulvey J, Telle S, Nigrelli L, Lamour K, Thines M (2010) Salisapiliaceae - a new family of oomycetes from marsh grass litter of southeastern North America. Persoonia 25:109-116

Huson DH, Auch AF, Qi J, Schuster SC (2007) MEGAN analysis of metagenomic data. Genome Res 17:377-386

Kageyama K, Senda M, Asano T, Suga H, Ishiguro K (2007) Intra-isolate heterogeneity of the ITS region of rDNA in Pythium helicoides. Mycol Res 111:416-423

Klosterman SJ, Anchieta A, McRoberts N, Koike ST, Subbarao KV, Voglmayr H, Choi Y-J, Thines M, Martin FN (2014) Coupling spore traps and quantitative PCR assays for detection of the downy mildew pathogens of spinach (Peronospora effusa) and beet (P. schachtii). Phytopathol 104:1349-1359

Lafferty KD et al (2008) Parasites in food webs: the ultimate missing links. Ecol Lett 11:533-546

Lafferty KD, Dobson AP, Kuris AM (2006) Parasites dominate food web links. PNAS 103:11211-11216

Langer JA, Sharma R, Schmidt SI, Bahrdt S, Horn HG, Algueró-Muñiz M, Nam B, Achterberg EP, Riebesell U, Boersma M, Thines M, Schwenk K (2017) Community barcoding reveals little effect of ocean acidification on the composition of coastal plankton communities: evidence from a long-term mesocosm study in the Gullmar Fjord, Skagerrak. PloS ONE 12:e0175808

Man in 't Veld WA, Rosendahl KC, Brouwer H, de Cock AW (2011) Phytophthora gemini sp. nov., a new species isolated from the halophilic plant Zostera marina in the Netherlands. Fungal Biol 115: 724-732

Marano AV, Jesus AL, De Souza JI, Jerônimo GH, Gonçalves DR, Boro MC, Rocha SCO, Pires-Zottarelli CLA (2016) Ecological roles of saprotrophic Peronosporales (Oomycetes, Straminipila) in natural environments. Fungal Ecol 19:77-88 
Nigrelli L, Thines M (2013) Tropical oomycetes in the German Bight climate warming or overlooked diversity? Fungal Ecol 6:152-160

Pottorff LP, Panter KL (1997) Survey of Pythium and Phytophthora spp. in irrigation water used by Colorado commercial greenhouses. HortTechnology 7:153-155

Robideau GP et al (2011) DNA barcoding of oomycetes with cytochrome c oxidase subunit I and internal transcribed spacer. Mol Ecol Res 11: 1002-1011

Scholz B, Kupper FC, Vyverman W, Karsten U (2014) Eukaryotic pathogens (Chytridiomycota and Oomycota) infecting marine microphytobenthic diatoms - a methodological comparison. J Phycol 50:1009-1019

Scholz B, Küpper FC, Vyverman W, Karsten U (2016) Effects of eukaryotic pathogens (Chytridiomycota and Oomycota) on marine benthic diatom communities in the Solthörn tidal flat (southern North Sea, Germany). Eur J Phycol 51:253-269

Sekimoto S, Beakes GW, Gachon CM, Muller DG, Kupper FC, Honda D (2008a) The development, ultrastructural cytology, and molecular phylogeny of the basal oomycete Eurychasma dicksonii, infecting the filamentous phaeophyte algae Ectocarpus siliculosus and Pylaiella littoralis. Protist 159:299-318

Sekimoto S, Yokoo K, Kawamura Y, Honda D (2008b) Taxonomy, molecular phylogeny, and ultrastructural morphology of Olpidiopsis porphyrae sp. nov. (Oomycetes, Straminipiles), a unicellular obligate endoparasite of Bangia and Porphyra spp. (Bangiales, Rhodophyta). Mycol Res 112:361-374

Sharma R, Thines M (2015) FastQFS - a tool for evaluating and filtering paired-end sequencing data generated from high throughput sequencing. Mycol Prog 14:1-7

Sime-Ngando T, Lefèvre E, Gleason FH (2011) Hidden diversity among aquatic heterotrophic flagellates: ecological potentials of zoosporic fungi. Hydrobiologia 659:5-22

Singer D et al (2016) High-throughput sequencing reveals diverse oomycete communities in oligotrophic peat bog micro-habitat. Fungal Ecol 23:42-47

Smith G, Ramsay A (2012) PEI Mussel Monitoring Program. (Technical Report \# 250) Retrieved from http://www.gov.pe.ca/photos/ original/FARD_Tech250.pdf

Sparrow FK (1960) Aquatic phycomycetes, 2nd edn. University of Michigan Press, Ann Arbor
Sparrow FK (1969) Zoosporic marine fungi from the Pacific Northwest (U.S.A.). Arch Mikrobiol 66:129-146

Strittmatter M, Gachon CMM, Küpper FC (2008) Ecology of lower oomycetes. In: Lamour K, Kamoun S (eds) Oomycete genetics and genomics. John Wiley \& Sons, Inc., pp 25-46

Tamura K, Peterson D, Peterson N, Stecher G, Nei M, Kumar S (2011) MEGA5: molecular evolutionary genetics analysis using maximum likelihood, evolutionary distance, and maximum parsimony methods. Mol Biol Evol 28:2731-2739

Thines M (2014) Phylogeny and evolution of plant pathogenic oomycetes - a global overview. Eur J P1 Pathol 138:431-447

Thines M, Kruse J (2017) Oomyceten im Winter. Z Mykol 83:337-347

Thines M, Choi YJ (2016) Evolution, diversity, and taxonomy of the Peronosporaceae, with focus on the genus Peronospora. Phytopathol 106:6-18

Thines M, Kamoun S (2010) Oomycete-plant coevolution: recent advances and future prospects. Curr Opinion Pl Biol 13:427-433

Thines M, Nam B, Nigrelli L, Beakes G, Kraberg A (2015) The diatom parasite Lagenisma coscinodisci (Lagenismatales, Oomycota) is an early diverging lineage of the Saprolegniomycetes. Mycol Prog 14: 75

Thompson RM, Mouritsen KN, Poulin R (2005) Importance of parasites and their life cycle characteristics in determining the structure of a large marine food web. J Anim Ecol 74:77-85

Wetsteyn LPMJ, Peperzak L (1991) Field observations in the Oosterschelde (The Netherlands) on Coscinodiscus concinnus and Coscinodiscus granii (Bacillariophyceae) infected by the marine fungus Lagenisma coscinodisci (Oomycetes). Hydrobiol Bull 25: $15-21$

Wilce RT, Schneider CW, Quinlan AV, Bosch K (1982) The life history and morphology of free-living Pilayella littoralis (L.) Kjellm. (Ectocarpaceae, Ectocarpales) in Nahant Bay, Massachusetts. Phycol 21:336-354

Wood CL, Byers JE, Cottingham KL, Altman I, Donahue MJ, Blakeslee AMH (2007) Parasites alter community structure. PNAS 104:93359339

Publisher's Note Springer Nature remains neutral with regard to jurisdictional claims in published maps and institutional affiliations. 